\title{
PERANAN ORANG TUA DALAM MENINGKATKAN PRESTASI BELAJAR ANAK
}

\author{
Nur Afni, Jumahir
}

\begin{abstract}
Family is the main educational media for student development, in order to develop their potential both physically and spiritually by optimizing family's environment role as an educational environment. Some of these roles are as follows: paying attention to students' progress, engaging in learning activities, creating a learning atmosphere, providing learning guidance, and providing learning motivation to students. Learning achievement is students' ability to achieve certain subjects matter according to the curriculum, time, and certain criteria. Student's learning achievement is affected by various factors from outside themselves (external). The achievements are essentially the results of interactions with their environment, which are family environment and school environment as the education center.
\end{abstract}

Keywords: Parents' Role on Children

\section{PENDAHULUAN}

Pendidikan keluarga merupakan pendidikan yang utama dan pertama yang mempunyai tanggungjawab khusus terhadap pendidikan anak. Keluarga sebagai unit terkecil dalam masyarakat terbentuk berdasarkan sukarela dan cita yang azali antara dua subyek manusia (suami-isteri). Berdasarkan cinta yang azali ini lahirlah anak sebagai generasi penerus. Keluarga dengan cinta kasih dan pengabdian yang luhur membina kehidupan sang anak.

Orang tua memegang peranan penting dalam memikul tanggungjawab pendidikan anak. Pada saat ini pemeliharaan dan pembiasaan sangat penting dalam pelaksanaan pendidikan. Kasih sayang orang tua yang tumbuh akibat dari hubungan darah dan diberikan kepada anak secara wajar atau sesuai dengan kebutuhan bagi pertumbuhannya. Kekurangan belaian kasih sayang orang tua menjadikan anak keras kepala, sulit diatur, mudah memberontak, dan lain-lain. Akan tetapi kasih sayang yang berlebihan menjadikan anak manja, penakut, tidak cepat untuk dapat hidup mandiri. Orang tua dengan penuh cinta kasih 
109| MUSA WA, Vol. 12 No.1 Juni 2020 : 108-139

mengabdikan seluruh hidupnya untuk membesarkan dan mendidik anak agar mampu hidup mandiri dimasa depan. Pendidikan yang diberikan orang tua sangat berpengaruh bagi perkembangan watak, budi pekerti, dan kepribadian anak mereka.

Keluarga adalah wadah pertama dan utama bagi pertumbuhan dan pengembangan perilaku peserta didik, dan keluarga juga dianggap sebagai awal dari proses pendidikan (khususnya pendidikan agama Islam), serta dengan adanya kebiasaan-kebiasaan dalam lingkungan keluarga maka peserta didik secara tidak langsung akan berperilaku seperti apa yang telah menjadi kebiasaan orang tua dalam lingkungan keluarga.

Hal tersebut sesuai dengan pernyataan Zakiah Daradjat, bahwa:

Orang tua adalah Pembina pribadi yang pertama dalam kehidupan anak. Kepribadian orang tua, sikap dan cara hidup mereka, merupakan unsur pendidikan yang tidak langsung, yang dengan sendirinya akan masuk ke dalam pribadi anak yang sedang tumbuh dan berkembang. Sikap anak terhadap guru dan pendidikan agama sangat dipengaruhi oleh orang tuanya terhadap agama bagi anak-anaknya. ${ }^{1}$

Memahami pandangan di atas dapat dijelaskan bahwa perlakuan orang tua terhadap anak, merupakan unsur pembinaan dalam pribadi anak. Perlakuan keras, akan berlainan akibatnya dibanding perlakuannya yang lembut dalam membentuk kepribadian anak. Dengan kata lain apabila orang tua memberikan pendekatan yang baik, misalnya menanamkan kebiasaan-kebiasaan yang baik pada awal kehidupan anak dalam kehidupan sehari-hari seperti, melaksanakan shalat lima waktu, berpuasa di bulan suci Ramadhan, menolong orang lain yang membutuhkannya serta memberikan bimbingan dan nasehat-nasehat yaitu tentang perilaku-perilaku yang baik dilakukan dan yang tidak baik dilakukan.

Dengan adanya pembiasaan-pembiasaan tersebut, diharapkan peserta didik dapat mengaplikasikannya di masyarakat luas khususnya di lembaga formal (sekolah). Akan tetapi, apabila orang tua memberikan pendekatan pembiasaan yang buruk, misalnya menanamkan kebiasaan-kebiasaan perlakuan dan perkataan yang kasar, perselisihan dalam keluarga dan lain-lain. Sehingga adanya kebiasaan-

${ }^{1}$ Zakiah Daradjat, Ilmu Jiwa Agama, (Cet.VIII; Jakarta: Bulan Bintang, 1989), h. 71 
kebiasaan tersebut maka peserta didik secara tidak langsung akan berperilaku seperti apa yang telah menjadi kebiaasaan orang tua dalam lingkungan keluarga. Serta akan terimplikasi terhadap perilaku peserta didik dalam lingkungan masyarakat, khususnya dalam lingkungan formal (sekolah).

Pendidikan keluarga merupakan pendidikan dasar bagi pembentukan jiwa peserta didik. Fungsi dan peran orang tua yaitu mampu membentuk perilaku anakanak mereka. Bayi yang dilahirkan sudah memiliki potensi, namun bentuk pendidikan yang dijalani anak sepenuhnya tergantung dari bimbingan, pemeliharaan dan pengaruh kedua orang tua mereka.

M. Yusran Asmuni menyatakan:

Bahwa lingkungan keluarga adalah tempat yang pertama dan utama pendidikan yang dialami oleh peserta didik. Dalam keluarga peserta didik bergaul, tumbuh dan berkembangnya dan sebagian besar hidup dan kehidupannya sebelum dewasa berada dalam lingkungan keluarga. Karena itu lingkungan kepribadian peserta didik yang nantinya dapat dibina dan dikembangkan dalam pendidikan selanjutnya. ${ }^{2}$

Dari pernyataan di atas, dapat dikatakan bahwa keluarga adalah wadah pertama dan utama bagi pertumbuhan dan pengembangan perilaku peserta didik keluarga juga dianggap sebagai awal dari proses pendidikan juga mampu memberikan arahan dan keyakinan bagi anak didik, "Bahwa keluarga memberikan keyakinan agama, menanamkan nilai budaya, nilai moral, etika dan kepribadian estetika, serta meningkatkan pengetahuan dan keterampilan peserta didik dalam rangka mencapai tujuan pendidikan nasional."3

Adaptasi untuk menyelaraskan diri dengan perkembangan kehidupan masayarakatnya, seseorang memerlukan pendidikan searah dengan kepentingan itu maka dibentuk lembaga khusus untuk menyelenggarakan tugas-tugas kependidikan.

Dengan demikian secara kelembagaan maka sekolah pada hakekatnya adalah merupakan lembaga pendidikan formal, sejalan dengan fungsi dan perannya maka sekolah sebagai lembaga pendidikan adalah pelanjut dari

\footnotetext{
${ }^{2}$ H.M. Yusran Asmuni, Psikologi Pendidikan, (Jakarta: Gema Insan Press, 1988), h. 33

${ }^{3}$ Abdul Rachman Shaleh, Pendidikan Agama Islam dan Pembangunan Watak Bangsa, (Edisi, Jakarta : PT. Raja Grafindo Persada, 2005), h. 270
} 
pendidikan keluarga (khususnya pendidikan agama Islam dalam keluarga), karena keterbatasan dari para orang tua untuk mendidik anak-anak mereka, yang dipengaruhi oleh berbagai faktor kegiatan orang tua, di antaranya kesibukan di masyarakat, pekerjaan di luar rumah maupun pekerjaan rumah. Dengan berbagai pernyataan di atas, maka sebahagian besar orang berpendapat bahwa tanggung jawab pendidikan agama Islam terhadap anak merupakan tugas guru agama di sekolah. Seluruh produk pendidikan seolah-olah tanggung jawab guru dan seluruh perangkatnya. Padahal dari seluruh waktu sepanjang hari (24 jam), anak berada di sekolah hanya sekitar 6 jam. Secara logika, tidak mungkin sekolah yang hanya memiliki waktu sekitar seperempat hari itu menjadi faktor penentu untuk membentuk kepribadian peserta didik. Maka dengan berbagai alasan tersebut mereka diserahkan orang tua ke sekolah-sekolah.

Orang tua mempunyai tugas yang cukup berat, yaitu secara langsung membina kepribadian peserta didik. Harus memperbaiki kepribadian peserta didik yang terlanjur rusak, karena faktor pendidikan keluarga. Orang tua harus bekerja secara intensif untuk membawa peserta didiknya kepada arah pembinaan pribadi yang sehat. Serta setiap orang tua harus menyadari bahwa segala sesuatu pada dirinya akan merupakan unsur pembinaan untuk semua peserta didiknya.

Orang tua mempunyai peranan yang sangat strategis dan signifikan dalam pembentukan moral, akhlak dan etika peserta didik yang sekarang ini sedang berada pada titik terendah dalam perkembangan masyarakat Indonesia. Oleh karena itu untuk membentuk anak didik yang baik, bertanggung jawab dan berakhlak, perlu adanya pendidikan yang efektif baik di sekolah (formal) maupun keluarga (informal).

Salah satu kegagalan orang tua dalam membentuk perilaku peserta didik adalah kurangnya kontrol terhadap pergaulan anak didik sehari-hari di lingkungan masyarakat. Padahal quality control itu seharusnya menjadi pegangan dalam melaksanakan proses pendidikan agama Islam, sejak di tingkat input kemudian diproses sampai pada outputnya.

Wujud pengaruh lingkungan akan terbiasa pada perkembangan jiwa anak didik. Kalau dominasi lingkungan adalah pengaruh keagamaan, maka akan terbiasa pada perilaku dan aktifitas keseharian anak berupa perilaku 
keagamaan, begitupun sebaliknya dominasi lingkungan bukan pengaruh agama, maka akan terbiasa pada aktifitas keseharian remaja berupa perilaku kebrutalan. ${ }^{4}$

Keterpaduan pendidikan baik keluarga, sekolah dan masyarakat sangat menentukan keberhasilan dalam dunia pendidikan. Keluarga merupakan lembaga pendidikan tertua, yang pertama dan utama dialami oleh anak dan lembaga pendidikan yang bersifat kodrat. Sekolah sebagai lembaga pendidikan formal hakekatnya merupakan lembaga yang mendapatkan kepercayaan dari orang tua untuk mendidik anak-anaknya dengan tanggung jawab yang terbatas, sesuai dengan fungsi dan tujuan lembaga pendidikan tersebut.

Orang tua mempunyai andil keberhasilan anaknya. Kadang-kadang tanggung jawab itu kurang disadari oleh orang tua sehingga sering timbul bahwa kurangnya keberhasilan anaknya merupakan akibat dari kurangnya perhatian dan tanggung jawab pengelola pendidikan.

Prestasi belajar anak bukan semata-mata merupakan hasil proses belajar di sekolah saja. Melainkan ditunjang dari peran orang tua di rumah. Peran orang tua terhadap anak terasa sekali bilamana didukung oleh latar belakang pendidikan yang memadai. Karena keberhasilan pendidikan anak tidak semata-mata hanya ditentukan oleh sekolah saja.

\section{PEMBAHASAN}

\section{Peranan dan Prestasi Belajar}

Kata peran berarti laku, bertindak. Didalam kamus besar bahasa Indonesia peran ialah perangkat tingkah laku yang diharapkan dimiliki oleh orang yang berkedudukan di masyarakat. ${ }^{5}$ Sedangkan makna peran yang dijelaskan dalam Status, Kedudukan dan Peran dalam masyarakat, dapat dijelaskan melalui beberapa cara, yaitu pertama penjelasan histories. Menurut penjelasan histories, konsep peran semula dipinjam dari kalangan yang memiliki hubungan erat dengan

\footnotetext{
${ }^{4}$ Dadang Hawari, Al-Qur'an, Ilmu Kedokteran Jiwa dan Kesehatan Jiwa (Cet, IX; Yogyakarta: PT. Dana Bhakti Prima Yasa, 1999), h. 7

${ }^{5}$ E.St Harahap, dkk. Kamus besar bahasa Indonesia (Bandung: Balai Pustaka, 2007), 854
} 
113 | MUSA WA, Vol. 12 No.1 Juni 2020 : 108-139

drama atau teater yang hidup subur pada zaman yunani kuno atau romawi. Dalam hal ini, peran berarti karakter yang disandang atau dibawakan oleh seorang actor dalam sebuah pentas dengan lakon tertentu. Kedua, pengertian peran menurut ilmu sosial. Peran dalam ilmu sosial berarti suatu fungsi yang dibawakan seseorang ketika menduduki jabatan tertentu, seseorang dapat memainkan fungsinya karena posisi yang didudukinya tersebut.

Setiap pekerjaan menginginkan hasil, prestasi merupakan hasil maksimal yang dicapai dalam aktifitas, seperti kegiatan belajar juga menginginkan prestasi yang baik. Prestasi dapat mengangkat motivasi seseorang untuk terus berkarya, menghasilkan yang terbaik dalam kehidupannya, sehingga dengan berprestasi dalam kehidupan ini, seseorang memiliki kepercayaan diri. Untuk mengetahui berhasil tidaknya seseorang dalam belajar, memerlukan ukuran. Dengan mengukur hasil belajar seseorang dapat diketahui batas kemampuan, kesanggupan, pengetahuan, keterampilan, sikap atau niai dalam rangka menyelesaikan suatu pelajaran.

Hasil yang dicapai tiap-tiap peserta didik belum tentu sama, karena keadaan dan cara belajar yang digunakan mungkin berbeda. Seseorang peserta didik yang rajin dan tekun belajar, akan mendapat prestasi belajar yang baik. Dalam kamus umum bahasa Indonesia, prestasi ialah hasil yang dicapai, tinggi rendahnya satu nilai sebagai hasil yang dicapai oleh seseorang, itulah yang disebut prestasi. $^{6}$

Prestasi menunjukan segala pekerjaan yang berhasil dan menunjukan kecakapan manusia sehingga prestasi adalah hasil dari suatu kegiatan nyata yang berupa kemampuan,kecakapan atau nilai. Prestasi belajar sebagai kualitas dan pengetahuan yang dikuasai oleh peserta didik, sedangkan seringnya seseorang berprestasi maka dapat dipahami, bahwa ia menguasai bidangnya dengan baik. Jadi peserta didik yang berprestasi adalah peserta didik yang menguasai bidang mata pelajaran dengan sempurna.

\footnotetext{
${ }^{6}$ W. J. S. Poerwadarminta, Kamus Umum Bahasa Indonesia. ( Cet. VI; Jakarta: PN. Balai Pustaka, 1983 ), 768
} 
Prestasi belajar adalah hasil yang dicapai setelah melakukan kegiatan belajar, hasil tersebut merupakan kecakapan nyata yang dapat diukur langsung dengan menggunakan uji hasil belajar. Prestasi belajar diwujudkan dalam bentuk angka, ini dapat dilihat pada daftar nilai mata pelajaran, yng diperoleh oleh peserta didik setelah mengikuti ujian. Prestasi belajar merupakan salah satu kreteria untuk menilai kemajuan pendidikan, karena itu segala upaya diarahkan agar pencapaian prestasi belajar dapat diraih secara maksimal oleh peserta didik.

Proses pembelajaran di sekolah merupakan satu kesatuan yang tersusun dan teratur, terdiri dari unsure tujuan, materi, kegiatan pembelajaran, media dan juga unsure lain yakni peserta didik, pendidik, rangsangan dan evaluasi.

Penilaian prestasi belajar menjadi kegiatan yang tidak dapat dipisahkan dengan proses pembelajaran di sekolah, dimaksudkan untuk mengetahui penguasaan materi pelajaran oleh peserta didik setelah mengikuti dan menyelesaikan suatu program pembelajaran. Untuk mencapai prestasi belajar, maka peserta didik seharusnya tekun belajar, yang menunjukan perubahan pola perilaku, makin banyak kemampuan yang diperoleh, sampai menjadi milik pribadi, maka makin banyak perubahan yang telah dialami. ${ }^{7}$

Pada dasarnya kegiatan belajar di sekolah memerlukan perubahan dalam tiga bidang, yakni kognitif, afektif dan psikomotor, tingkat kedalaman perubahan sesuai dengan pelajaran yang diamati oleh peserta didik. Kemampuan koginitif yang meliputi pengetahuan dan pemahaman, kemampuan sensorik psikomotorik yang meliputi keterampilan melakukan rangkaian gerak - gerik dalam urutan tertentu, sedang kemampuan dinamik afektif yang meliputi sikap dan nilai yang meresapi perilaku dan tindakan. ${ }^{8}$

Belajar sebagai sarana untuk meningkatkan prestasi belajar peserta didik, harus dijadikan proses perubahan secara efesien, efektif dan bermakna. Pembelajaran efektif adalah memudahkan peserta didik belajar seseuatu yang bermanfaat seperti fakta, keterampilan, nilai, konsep, cara hidup serasi dengan sesame, atau suatu hasil belajar yang diinginkan. Hubungan prestasi belajar

\footnotetext{
${ }^{7}$ W. S. Winkel, Psikologi Pengajaran, ( Cet, II; Jakarta: PT. Gramedia, 1989 ), 34

${ }^{8}$ Ibid. 36
} 
115 | MUSA WA, Vol. 12 No.1 Juni 2020 : 108-139

dengan peranan orang tua sangat kuat, sebab setiap orang tua menginginkan anaknya berkembang secara sempurna, orang tua menginginkan anak yang dilahirkan itu kelak menjadi orang yang sehat, kuat, berketerampilan, cerdas, pandai dan beriman. ${ }^{9}$

Semua orang tua ingin meraih cita-cita ideal, yaitu berprestasi dalam belajar anaknya, maka orang tua harus bertindak sebagai pendidik utama, bertanggungjawab tentang pendidikan dalam rumah tangga. Pemahaman dan pengetahuan tentang pendidikan rumah tangga ini, dapat menjadi rambu dalam menuntun anaknya, agar dapat berhasil dalam kehidupannya.

Orang tidak dapat saja membuat kurikulum seperti yang ada di sekolah namun tentunya lebih sederhana dan mencakup garis besarnya saja, kurikulum itu dapat berupa pembinaan jasmani dan keterampilan, pengembangan akal dan penyehatan rohani. Teori ini mengacu pada aspek kepribadian dalam rangka memacu potensi anak.

Untuk merangsang kecerdasan anak, orang tua dapat mengembangkan potensi akalnya dengan cara memasukkan anaknya ke sekolah bermutu, di samping itu orang tua dapat terus mengasah otak anaknya misalnya dengan mengajak diskusi, menyelesaikan masalah dengan anak analisis akal, tindakan orang tua senantiasa rasional, membantu anak menyelesaikan pekerjaan rumahnya juga menanamkan pada anak tentang pentingnya memiliki akal cerdas dan rasional.

Kewajiban mendidik anak harus dilakukan orang tua sebagai fitrah kasih saying, guna mendorong peningkatan kecerdasan, orang tua melatih dan mengajar anaknya segala bentuk keterampilan dan ilmu pengetahuan, mulanya anak hanya meniru kemudian berangsur-angsur melakukan dan pada akhirnya anak menjadi mahir.

Secara psikologis perintah mendidik anak menjadi tuntutan fitrah manusia ketika seorang telah menjadi ayah dan ibu, selanjutnya ada keinginan mengasuh,

\footnotetext{
${ }^{9}$ Ahmad Tafsir, Ilmu Pendidikan dalam Prespektif, ( Cet, II; Bandung: PT. Remaja Rosdakarya, 1994 ), 155
} 
memelihara, menyelamatkan dan mendidik anak. ${ }^{10}$ Orang tua dapat memprogramkan segala hal yang berhubungan dengan peningkatan kualitas kecerdasan anaknya. Pendidikan anak yang ingin diarahkan untuk meningkatkan kecerdasannya, lingkungan perlu dirangsang secara edukatif, orang tua menjadi penggerak menciptakan lingkungan yang mendidik setiap prilaku anak, suasana rumah tangga yang membuat anak senantiasa terangsang untuk mengetahui hal yang baru perlu diciptakan.

Orang tua sebagai manajer dalam kehidupan rumah tangga, dapat mengatur dengan seksama agar anak dapat belajar dengan baik, sehingga akalnya dapat berkembang dengan teratur, jauhkan anak dari kebiasaan yang tidak memiliki landasan. Islam menolak ilmu yang diperoleh tanpa melalui pemikiran, penelitian dan penggunaan akal. Islam mencela orang-orang yang meniru ulah nenek moyang, hal ini diterangkan dalam firman Allah sebagai berikut:

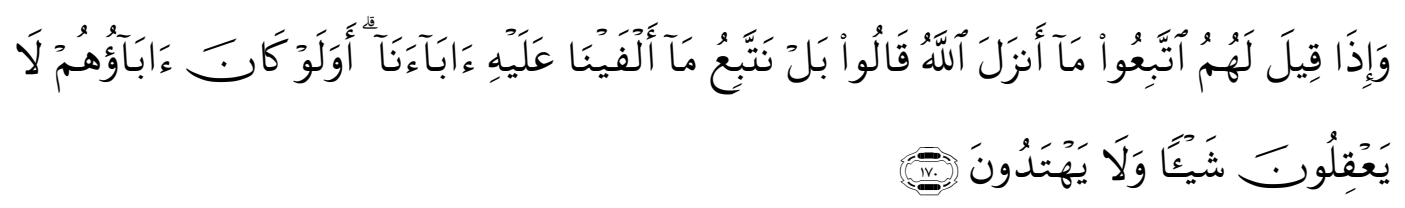

Terjemahnya:

Dan apabila dikatakan kepada mereka: "Ikutilah apa yang telah diturunkan Allah," mereka menjawab: "(Tidak), tetapi Kami hanya mengikuti apa yang telah Kami dapati dari (perbuatan) nenek moyang kami". "(Apakah mereka akan mengikuti juga), walaupun nenek moyang mereka itu tidak mengetahui suatu apapun, dan tidak mendapat petunjuk?". (Q.S. AlBaqarah (02) : 170). ${ }^{11}$

Anak diarahkan oleh orang tua, agar senantiasa mendasari perbuatan pada kebenaran, prasangka tidak akan menghantarkan pada ilmu, bahkan cenderung untuk keliru. Hal ini telah diinformasikan oleh Allah swt. Dalam alqur'an sebagai berikut:

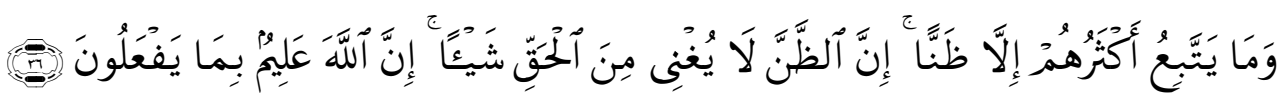

\footnotetext{
${ }^{10}$ Baihaqi A. K. Mendidik Anak Dalam Kandungan Menurut Pedagogis Islam, ( Cet. I; Jakarta: Darul Ulum Press, 2000 ), 60 32.

${ }^{11}$ Kementrian Agama RI, Alquran dan Terjemahnya (Jakarta: PT. Sinergi Pustaka, 2012),
} 
117| MUSA WA, Vol. 12 No.1 Juni $2020: 108-139$

Terjemahnya:

Dan kebanyakan mereka tidak mengikuti kecuali persangkaan saja. Sesungguhnya persangkaan itu tidak sedikitpun berguna untuk mencapai kebenaran. Sesungguhnya Allah Maha mengetahui apa yang mereka kerjakan. (Q.S. Yunus (10): 36). ${ }^{12}$

Orang tua senantiasa memberikan pandangan terhadap anaknya, tentang pengetahuan berdasarkan hasil pengujian yang mengantar anak memahami kebenaran yang rasional. Bertahap dari yang konkrit kepada yang abstrak dan dari yang persial kepada yang global. Dalam hal ini perlu dibuka diskusi, sehingga terbuka pemahaman yang luas tentang segala sesuatu. Menyaring dan menguji pendapat sebelum mengambilnya, Islam menuntun agar tidak menjadikan hawa nafsu sebagai penglima dalam mengambil keputusan. Allah swt. Memerintahkan agar menjauhi dari hawa nafsu. Firman Allah swt. Sebagai berikut:

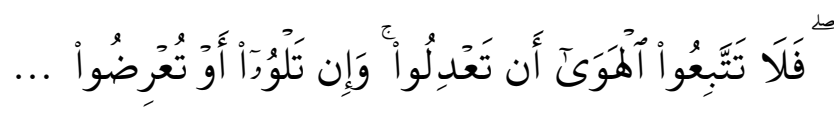

Terjemahnya:

Maka janganlah kamu mengikuti hawa nafsu karena ingin menyimpang dari kebenaran. dan jika kamu memutar balikkan (kata-kata) atau enggan menjadi saksi... (Q.S. An - Nisa (04): 135). ${ }^{13}$

Orang tua dapat membantu anaknya kea rah penggunaan akalnya, sehingga kemampuan berpikir, merekontruksi dan mengambil pelajaran senantiasa dilaksanakan sejak dini. Tertanamlah tradisi keilmuan, yang dituntun oleh nilai pendidikan yang berbasis Islami, pada tahap selanjutnya lingkungan dan lembaga pendidikan lebih memoles anak, menjadi anak yang cerdas dan pada gilirannya anak anak berprestasi. ${ }^{14}$

Program yang dilakukan orang tua untuk menciptakan anak yang bermutu, senantiasa berprestasi dalam kehidupannya, akan menjadi kontribusi dalam menciptakan sumber daya yang handal. Orang tua sebagai posisi terdepan dalam keluarga akan memiliki peluang untuk membentuk peribadi anak bangsa yang

\footnotetext{
12 Ibid, 285.

${ }^{13}$ Ibid, 131

${ }^{14}$ Abdul Fattah Jalal, Min al-Ushulit at-Tarbawiyah Fi al-Islam, Alih Bahasa Herry noer Ali, dengan judul Azaz - azaz Pendidikan Islam, ( Cet., I; Bandung: CV. Diponegoro, 1988 ), 177
} 
dapat berkompetisi dalam menjawab tantangan zaman yang terus berubah. Masyarakat akan baik bila ditopang oleh keluarga yang utuh, demikian pula bangsa akan jaya bila ditopang oleh masyarakat yang utuh pula.

Orang tua senantiasa menanamkan tradisi keilmuan kepada anaknya, menurut Al-Qur'an ilmu adalah suatu keistimewaan pada manusia, yang menyebabkan manusia unggul dari makhluk lain. Kedudukan akal dalam Islam sangat tinggi, dengan mempergunakan akalnya, manusia dapat berbuat, memahami dan mewujudkan sesuatu. ${ }^{15}$ Demikian pula orang tua memberi motivasi, agar anaknya senatiasa menjadikan ilmu bagian dari hidupnya, maka anak biasa dengan pemahaman dan pengertian secara rasional.

Orang tua harus mempersiapkan anaknya, agar mampu hidup mandiri dan mampu melaksanakan tugas dengan sebaik-baiknya, termasuk mempersiapkan intelektualnya. Menurut Al-Gazali klasifikasi ilmu terdiri dari, ilmu keagamaan dan ilmu kecerdasan pikiran (Intelektual). ${ }^{16}$ Orang tua berkepentingan untuk mewariskan nilai intelektual kepada anaknya agar siap mewariskan pengalaman, pengetahuan, kemampuan dan keterampilan yang melatarbelakangi nilai dan norma kehidupan dan inilah yang disebut pendidikan. ${ }^{17}$

Proses pendidikan yang dilakukan oleh orang tua tumbuh dan berkembang sesuai perkembangan anak, bagi orang tua yang memiliki pengetahuan yang memadai, dengan mudah menyesuaikan dengan perkembangan zaman. Orang tua akan memberikan peluang kepada anaknya, untuk mengembangkan dan mempersiapkan diri menghadapi perubahan yang sangat cepat.

Pendidikan adalah pengembangan potensi bawaan anak secara maksimal, orang tua berperan penting untuk mengembangkan potensi itu. Perkembangan ilmu pengetahuan dan teknologi sekarang ini, dapat saja dijadikan alat, untuk membantu mempercepat tujuan yang diprogramkan orang tua. Tujuan pendidikan berkaitan erat dengan tujuan hidup manusia, maka orang tua member adndil yang

\footnotetext{
${ }^{15}$ Mohammad Daud Ali. Pendidikan Agama Islam, ( Cet. II; Jakarta: PT. Raja Grafindo Persada, 1998 ), 386

${ }^{16}$ Ibid, 392

${ }^{17}$ Tadjab, Perbandingan Pendidikan Studi Perbandingan Tentang Beberapa Aspek Pendidikan Berat Modern, Islam dan Nasional, ( Cet. I: Surabaya: Karya Abditama, 1994 ), 136
} 
119 | MUSA WA, Vol. 12 No.1 Juni 2020 : 108-139

tidak kecil dalam mewujudkannya. Orang tua dapat merekayasa masa depan anaknya, dengan menanamkan daya analitik, memanfaatkan informasi, menggunakan kemajuan ilmu pengetahuan dan teknologi, memasukkan kepada lembaga yang merangsang daya nalarnya, dan mampu menjawab tantangan zaman. ${ }^{18}$ Dengan kreatifitas dan perencanaan yang matang orang tua dapat mengantar anaknya menjadi anak cerdas, memiliki keterampilan dan sikap yang pada akhirnya berprestasi dalam segala aspek kehidupannya.

\section{Upaya Untuk Meningkatkan Prestasi Belajar}

Proses pembelajaran memiliki prinsip - prinsip, dalam proses pembelajaran pendidik dituntut tidak hanya menggunakan satu metode,namun diharapkan dapat menggunakan beberapa metode, dalam menyelesaikan permasalahan dalam aktifitas tersebut. Metode pembelajaran yang dimaksud, mungkin berasal dari teori psikologi, sehingga ditemukan prinsip yang mendasari pembelajaran, yang relative berlaku umum dalam proses pembelajaran. Hal ini diyakini bahwa setiap teori pembelajaran memiliki prinsip sendiri. ${ }^{19}$

Inti kegiatan pembelajaran di sekolah, adalah interaksi antara pendidik dengan peserta ddik dalam mempelajari suatu materi pelajaran, yang telah tersusun dalam suatu kurikulum. Dalam proses pembelajaran, para pendidik diharapkan menguasai bahan ajar, disamping itu harus mengerti karakter peserta didik, yang menerima pelajaran dari pedidik itu. Kegagalan menyampaikan bahan ajar, banyak disebabkan oleh perilaku pendidik dalam menyampaikan teknik pembelajaran, yang tidak tepat dan tidak menarik. Penguasaan bahan ajar bukan satu - satunya cara, sehingga pendidik dapat menyajikan pelajarannya dengan baik, namun teknik yang menyenangkan dan mengasikkan, dalam menerima pelajaran menjadi kunci penerimaan pelajaran bagi peserta didik.

Setiap pendidik harus memiliki pola pembelajaran sendiri, pola pembelajaran ini tercermin dalam tingkah laku, pada waktu melaksanakan aktifitas pembelajaran. Dianne Lapp menamakan tingkah laku mengajar yang

\footnotetext{
${ }^{18}$ Ibid., 138

${ }^{19}$ Syaiful Sagala, Konsep dan Makna Pembelajaran, ( Cet. IV; Bandung: CV. Alfabeta, 2006 ), 150
} 
dimiliki pendidik dengan istilah gaya mengajar (Teaching Style). Gaya mengajar ini mencerminkan, bagaimana pelaksanaan pembelajaran yang dilakukan oleh seorang pendidik di mana ia dipengaruhi oleh pendangannya sendiri tentang pembelajarannya, konsep psikologi yang digunakan serta kurikulum yang jadi panduannya. $^{20}$

Dengan gaya mengajar yang diterapkan oleh seorang pendidik, maka diharapkan mampu mengakomodir perbedaan yang terjadi pada peserta didik, seperti perbedaan kecerdasan, bakat, minat, sikap dan lainya. Namun perinsip perinsip yang mendasari pembelajaran, hanya bias dilaksanakan dengan baik, bila seluruh komponen dapat bersinergi dengan harmonis, yaitu pendidik, peserta didik, materi ajar, lingkungan bahkan sarana prasarana.

Dalam upaya meningkatkan prestasi belajar peserta didik maka pendidik perlu melaksanakan hal - hal berikut:

1. Prinsip pembelajaran

Pada dasarnya seorang pendidik dapat menyusun prinsip pembelajaran, sebagai suatu kebutuhan dalam menyajikan pelajarannya. Prinsip ini dapat dilaksanakan dalam situasi dan kondisi yang berbeda, bagi setiap peserta didik secara individu. Ada beberapa prinsip pembelajaran antara lain:

a) Dalam pembelajaran setiap peserta didik harus diusahakan partisipasi aktif, meningkatkan minat dan membingbing untuk mencapai tujuan intruksional.

b) Pembelajaran bersifat keseluruhan dan materi itu harus memiliki struktur, penyajian yang sempurna, sehingga peserta didik mudah menangkap pengertiannya.

c) Pembelajaran harus dapat menimbulkan reinforcement (penguatan) dan motivasi yang kuat pada peserta didik untuk mencapai tujuan intruksional.

d) Pembelajaran itu proses continue (terus - menerus), harus tahap demi tahap menurut perkembangannya.

\footnotetext{
${ }^{20}$ Muhammad Ali, Guru Dalam Proses Belajar Mengajar, (cet. IX; Bandung: Sinar Baru Algensido, 1996 ), 5
} 
e) Pembelajaran adalah proses organisasi dan adaptasi.

f) Pembelajaran harus dapat mengembangkan kemampuan tertentu sesuai dengan tujuan intruksional yang harus dicapainya.

g) Pembelajaran memerlukan sarana yang cukup, sehingga peserta didik dapat belajar dengan tenang.

h) Pembelajaran perlu lingungan yang menantang, dimana peserta didik dapat mengembangkan kemampuannya bereksplorasi (penjelajahan) dan belajar dengan efektif.

i) Pembelajaran memerlukan interaksi antara peserta didik dengan lingkungannya.

j) Pembelajaran adalah proses kontiguitas (kontak), adalah hubungan antara pengertian yang satu dengan pengertian yang lain. Stimulus yang diberikan menimbulkan respons yang diharapkan.

k) Repetisi, dalam proses pembelajaran perlu ulangan berkali - kali agar pengertian itu mendalam pada peserta didik. ${ }^{21}$

Dengan melihat prinsip pembelajaran yang dikemukakan di atas, maka pada dasarnya beberapa komponen memiliki arti penting, dalam mencapai pembelajaran yang baik dan menarik, seperti pendidik perlu memiliki kompetinsi (kecakapan), sebagai sumber yang akan menularkan pengetahuannya kepada peserta didik.

Disamping itu peserta didik harus diberikan peluang yang luas, agar dapat menjajal kemampuannya, dengan potensi yang dimiliki setiap individu, membuka peluang menganalisis dan mencermati satu permasalahan, sehingga peserta didik senantiasa kreatif menemukan hal yang baru. Tentu saja lingkungan dan saran harus mendukung proses pembelajaran, yang berlangsung secara terencana dan terprogram dengan baik, maka dibutuhkan kintak yang serasi antara satu komponen dengan yang lainnya, sehingga tujuan pembelajaran dapat dicapai.

\footnotetext{
${ }^{21}$ Roestiyah N. K., Masalah-Masalah Ilmu Keguruan, ( cet. I; Jakarta: PT. Bina Aksara, $1982), 166$
} 


\section{Tingkat Kematangan}

Pada dasarnya peserta didik yang belajara di kelas,berada pada proses kematangan, dan terus mengadakan perkembangan dengan mengikuti perubahan. Kemampuan peserta didik dengan usia dengan tingkat kelas masing - masing memiliki ukuran dan standar, pada saat pendidik memilih bahan ajar dan metode mengajar, maka pendidik hendaknya memperhatikan dan menyesuaikan dengan tingkat kematangan peserta didik. Perubahan yang dilakukan oleh peserta didik ada yang cepat dan ada yang lambat, oleh karena itu pendidik harus memiliki kepekaan dan sabar dalam melayani peserta didik.

Pendidik menjadi tumpuan yang serius, dalam member pemahaman yang baik kepada peserta didik, sehingga kualitas pendidik harus diperhatikan misalnya usia pendidik, aktualisasi diri, antusias, efisiensi, latar belakang pendidikan serta jumlah kursus yang telah diikuti, menjadi pemicu terhadap kemampuan pendidik memahami perkembangan peserta didiknya. ${ }^{22}$

Dalam pembelajaran tingkat kematangan sangat dipengaruhi oleh psikologi, itulah sebabnya dalam interaksi antara individu, baik pendidik dan peserta didik, maupun antara peserta didik dengan lainya, terjadi proses kejiwaan. Dalam hal ini Syodih Sukmadinata mengatakan, bahwa seluruh kegiatan interaksi pendidikan, diciptakan bagi kepentingan peserta didik, yaitu membantu mengembangkan semua potensi dan kecakapan yang dimiliki setinggi-tingginya. ${ }^{23}$

Maka memahami tingkat kematangan, berhubungan langsung dengan psikologi, karena ilmu ini memahami keadaan dan prilaku manusia termasuk peserta didik, satu dengan yang lainya sangat berbeda. Bagi pendidik memahami psikologi ini menjadi amat penting, agar dapat mengetahui semua jenjang satuan pendidikan.

Para ahli psikologi dan pendidikan, pada umumnya berkeinginan, bahwa dua orang anak (yang kembar sekalipun), tidak pernah memiliki respons yang sama persis terhadap situasi pembelajaran di kelas. Keduanya sangat mungkin

\footnotetext{
${ }^{22}$ Hamzah B. Uno, Landasan Pendidikan, ( Cet. I; Gorontalo: Nurul Jannah, 2003 ), h. 51

${ }^{23}$ Syaiful Sagala, op. cit., h. 120
} 
123 | MUSA WA, Vol. 12 No.1 Juni 2020 : 108-139

berbeda dalam hal pembawaan, kematangan, jasmani, intelegensi, dan keterampilan motorik. $^{24}$

Jadi jelas pendidik harus memahami dan mengetahui, karakteristik dan sifat peserta didiknya, agar dapat mengetahui secara akurat, proses serta tahapan pembelajaran, yang diberikan pada peserta didiknya.

\section{Perbedaan Individual}

Tiap peserta didik memiliki cirri dan pembawaan yang berbeda, menerima pengaruh dan perlakuan dari keluarganya juga berbeda. Dari segi pisik saja, setiap peserta didik sudah berbeda, ada yang tinggi, pendek, kurus, dan gemuk, sedangkan secara psikis, ada yang cekatan, ada yang lamban, ada yang cerda dan ada yang kurang cerdas.

Untuk membantu peserta didik mengatasi masalah yang terjadi pada dirinya, maka pendidik harus memahami benar cirri peserta didiknya itu, baik dalam menyiapkan dan menyajikan pelajaran, maupun dalam memberikan tugas bimbingan. Pendidik hendaknya menyesuaikan dengan cirri dan bakat peserta didik, model pengajaran berprogram, penyesuaian belajar dengan perbedaan individu ini, sepenuhnya dapat dilakukan oleh pendidik dengan cara belajar secara individual. $^{25}$

Pada pembelajaran klasikal, pendidik mengajar pelajaran yang sama, bahan ajar yang sama, dengan cara yang sama, untuk semua peserta didik pada kelas itu, sehingga perbedaan individu diabaikan. Pendidik harus mampu mengkombinasikan, kegiatan pelayanan kelas, dengan pelayanan belajar individual dengan serasi, yaitu mendesain prosudur maupun alokasi waktu, yang memenuhi kebutuhan belajar peserta didik dalam kelas, yang menjadi tanggung jawab pendidik.

Pembelajaran model klasikal ini dapat disempurnakan dengan cara berikut:

a) Pendidik menggunakan metode dan strategi pembelajaran yang bervariasi, hal ini dapat membantu perbedaan kemampuan peserta didik.

\footnotetext{
${ }^{24}$ Ibid., h. 121

${ }^{25}$ Ibid., h. 151
} 
b) Menggunakan alat dan media pembelajaran yang dapat membantu peserta didik khususnya yang mempunyai kelemahan tertentu.

c) Pendidik memberikan bahan ajar tambahan kepada peserta didik yang pandai.

d) Pendidik memberikan bantuan atau bimbingan khusus kepada peserta didik kurang pandai atau lamban dalam belajar yang dilakukan dalam jam belajar maupun diluar jam belajar

e) Pemberian tugas dsesuaikan dengan minat dan kemampuan peserta didik. $^{26}$

Penerapan model diatas hendaknya dilakukan dengan cara elastis, hal ini untuk memberikan peluang yang luas kepada peserta didik untuk berkreasi, demikian pula member dinamika belajar secara variativ, member rangsangan untuk berinovasi, sehingga pelajaran akan dimaknai dengan baik dan santai.

4. Fungsional

Beberapa pengertian tentang mengajar sangat berbeda satu dengan lainnya misalnya, mengajar diartikan sebagai menyampaikan pengetahuan dari seorang pendidik kepada peserta didik, atau mengajar adalah menanamkan sikap dan nilai, pengetahuan dan keterampilan, dari seorang yang telah mengetahui dan menguasainya kepada seseorang yang belum mengetahui dan juga mengajar dapat diartikan sebagai membimbing seseorang dan sekelompok orang supaya belajar berhasil. $^{27}$

Secara funsional mengajar bersangkut paut dengan belajar, sehingga memiliki implikasi bahwa mengajar dapat diartikan membimbing berupa petunjuk, nasihat, pemberitahuan, motivasi (dorongan), tugas, yang seluruhnya dilaksanakan dengan enjoy (senang). Dapat pula diartikan membimbing anak hingga dewasa, dengan segala keadaan dalam bingkai yang lebih luas dikatakan sebagai belajar.

\footnotetext{
${ }^{26}$ Ibid., h. 152

${ }^{27}$ Engkoswara , Dasar - Dasar Metodologi Pengajaran, ( Cet, II; Jakarta: Bina Aksara, 1988 ), h. 1
} 
125 | MUSA WA, Vol. 12 No.1 Juni 2020 : 108-139

Mengajar dapat dilakukan di sekolah dan diluar sekolah, baik yang dikenal dengan belajar formal maupun norformal, belajar ini memiliki proses perubahan sikap secara bertahap, perubahan juga diarahkan agar peserta didik mencapai prestasi dengan penguasaan, penggunaan dan penilaian sikap, pengetahuan dan keterampilan dalam bidang tertentu.

Ada banyak teori belajar sehingga dalam praktik terdapat perpaduan teori, relative susah menganut satu teori, karena mengajar dalam kenyataanya sangat situsional, di mana keterlibatan manusia menjadi factor kesulitan mengambil satu ukuran, coba diamati teori yang dilakukan oleh J. Noall, yang mengemukakan bahwa belajar dilakukan dalam suasana rebut. Percobaan ini dilakukan di Detroit, suasana gaduh di pabrik mobil, bandingkan dengan suasan pendidik yang sedang ulangan, awalnya suasana tenang namun tatkala ada diantara peserta didik yang mulai beranjak dari bangkunya, disusul dengan suara yang gaduh menunjukan selesai, maka bagi yang belum selesai tampak meningkatkan konsentrasinya. ${ }^{28}$

Ini menunjukan bahwa teori yang dikemukakan J. Noall ada benarnya, namun tidak dapat diartikan bahwa setiap belajar harus dengan suasana gaduh, sekali lagi menunjukan situsional, maka teori lain juga dapat digunakan, apabila sesuai dengan kondisi peserta didik dan suasana mendukung.

5. Mengembirakan

Dalam memulai pelajaran, pendidik sangat perlu menjadikan peserta didik senang, sebab bila ini tidak terjadi, kepasipan peserta didik akan muncul. menyusunan aktifitas pembuka, agar peserta didik saling berinteraksin antara satu dengan yang lainnya, merasa lebih rileks, ikut berpikir dan memperlihatkan minat terhadap pelajaran. Aktifitas ini dapat dianggap sebagai hidangan pembuka sebelum makanan utama, hal ini dapat menjadikan peserta didik lebih berselera mengikuti pelajaran berikutnya. Bagi pendidik yang memulai pelajarannya dengan kontak yang menyenangkan apalagi mengembirakan, maka peserta didiknya lebih antusias dengan pelajaran yang disajikan.

\footnotetext{
${ }^{28}$ Ibid., h.4
} 
Di saat awal pelajaran ada 3 tujuan penting yang dicapai oleh pendidik, yang harus dimaknai mempunyai pengaruh yang tidak kecil walaupun mata pelajaran berlangsung 1 jam, adapun tujuan itu sebagai berikut:

a) Pembentukan tim. Membantu peserta didik untuk lebih mengenal satu sama lain dan menciptakan semangat kerja sama dan interdependensi.

b) Penilaian sederhana. Pelajari sikap, pengetahuan, dan pengalaman peserta didik.

c) Keterlibatan belajar langsung. Ciptakan minat awal terhadap pelajaran. $^{29}$

Tujuan di atas bila dapat dicapai, akan membantu menciptakan lingkungan belajar, yang melibatkan peserta didik, meningkatkan kemampuan peserta didik, dalam ambil bagian kegiatan belajar, bahkan menciptakan norma yang positip. Peran yang dilakukan oleh pendidik, yang tidak memakan waktu yang lama ini, sebelum masuk pada inti pelajaran yang seseungguhnya, dapat menarik perhatiaan peserta didik menjadi gembira mengikuti proses pembelajaran. Dari beberapa pembelajaran yang dijelaskan di atas ada lagi jenis belajar yang dibedakan menjadi, belajar informasi, belajar konsep, belajar prinsip, belajar keterampilan. ${ }^{30}$

Keselurahan metode ini dapat digunakan oleh pendidik, sebagai upaya mencari cara terbaik dalam proses pembelajaran, sehingga peserta didik senantiasa bergairah mengikuti pelajaran yang disajikan. Metode ini pula selalu harus diinovasi agar sesuai situasi dan kondisi. Mengingat pendidik menjadi salah satu factor penentu keberhasilan pembelajaran, maka upaya efektif adalah menjadikan pendidik sebagai fasilitator, dengan member peluang seluas - luasnya pada peserta didik, untuk mengembangkan gagasan secara kreatif, agar peserta didik selalu aktif, menyempurnakan gagasan miskonsepsi, sambil membangun pengetahuan yang lebih ilmiah.

\footnotetext{
${ }^{29}$ Melvin L. Silberman, Active Learning: 101 Strategies to Teach Any Subject, diterjemahkan oleh raisul muttaqien, Active Learning: 101 Cara Belajar Siswa Aktif, ( Cet. I; Bandung: Nusamedia dan Nuansa, 2004 ), h. 64

${ }^{30}$ Nana Sudjana , Cara Belajar Siswa Aktif Dalam Proses Belajar Mengajar, ( Cet. III; Bandung: Sinar Baru Algensido, 1996), h. 12
} 
Kepedulian pendidik terhadap peserta didiknya, akan melahirkan sebuah hubungan interaktif yang sangat erat. Secara otomatis hubungan ini akan menggugah hati peserta didik, untuk lebih giat dan tekun dalam belajar untuk berprestasi. Situasi dan kondisi ruangan kelas, dengan karakteristik ruangan kelas dan pendidik yang memberikan perasaan aman dan tentram, kesuksesan, tantangan kondusif sangat penting, karena dapat menciptakan lingkungan yang memotivasi peserta didik untuk berprestasi.

Pendidik dapat mengembangan harapan positif peserta didik, dengan menggunakan strategi - strategi intruksional, yang memaksimalkan kesempatan untuk sukses dan meminimalkan kemungkinan akan gagal, pendidik harus memberikan tantangan dan menumbuhkan perasaan tertantang pada peserta didik. Dengan demikian peserta didik akan terinspirasi, untuk melewati tantangan tersebut akan melahirkan kepuasan yang tidak terdefinisikan.

Di samping yang dijelaskan di atas, kurikulum juga dapat meningkatkan prestasi belajar, kurikulum diartikan sebagai susunan rencana pelajaran. Kurikulum dipandang sebagai suatu program pendidikan, yang direncanakan dan dilaksanakan untuk mencapai sejumlah tujuan pendidkan, kurikulum juga dapat mempengaruhi belajar pesrta didik. Kurikulum yang tidak tercapi sebagai target yang telah ditentukan, maka kurikulum itu perlu dimodifikasi kembali bahkan mengganti dengan yang lain.

Meninjau kembali kurikulum adalah tugas dan wewenang pemerintah (Diknas), perbaikan ini harus berorientasi pada prinsip relevansi, efesiensi, efektifitas, fleksbelitas dan prinsip pendidikan seumur hidup. Prinsip relevansi didasarkan bahwa pendidikan menghasilkan pendidik yang professional, sehingga dapat mengikuti laju dan berkembangnya pendidikan. Prinsip efisiensi dan efektifitas bahwa waktu yang ada dapat dimanfaatkan dengan baik, demikian pula daya dan tenaga dapat dioptimalkan kemampuannya, bahkan memilih bahan pelajaran yang diperlukan untuk meningkatkan prestasi peserta didik. Prinsip keluwesan atau fleksibelitas harus mempertimbangkan situasi dan kondisi yang ada. Prinsip pendidikan seumur hidup bahwa peserta didik selalu berkembang dalam proses pembelajaran termasuk dalam prestasi belajar dan prestasi hidup. 
Menurut pandangan pakar bahwa kurikulum bukan hanya sekedar memuat sejumlah mata pelajaran, akan tetapi termasuk pula di dalamnya segala usaha sekolah untuk mencapai tujuan yang diinginkan, baik usaha tersebut dilakukan di linkungan sekolah maupun di luar sekolah. ${ }^{31}$

Hasan langgulung berpendapat bahwa kurikulum adalah sejumlah pengalaman pendidikan, kebudayaan, sisial, olah raga, dan kesenian baik yang berada di dalam maupun di luar kelas yang dikelola oleh sekolah. ${ }^{32}$

Pendidikan juga dapat memanfaatkan berbagai sumber pengajaran yang terdapat di luar kelas, sepert perpustakaan, museum, pameran, majalah, surat kabar, televise, radio dan media lainnya. Dengan kurikulum yang seperti itu, peserta didik dapat terus mengikuti perkembangan kemajuan ilmu pengetahuan, teknologi, kebudayaan yang terjadi diluar kelas.

Dengan tuntutan perkembangan zaman yang begitu cepat, maka perancang kurikulum harus menetapkan cukupan kurikulum. Cukupan itu antara lain.

1. Bagian yang berkenaan dengan tujuan yang ingin dicapai oleh proses pembelajaran.

2. Bagian yang berisi pengetahuan, informasi, data, aktifitas dan pengalaman yang merupakan bahan bagi penyusunan kurikulum yang isinya berupa mata pelajaran yang kemudian dimasukkan dalam silabus.

3. Bagian yang berisi metode atau cara menyampaikan mata pelajaran tersebut

4. Bagian yang berisi metode atau cara melakukan penilaian dan pengukuran atas hasil pengajaran mata pelajaran tertentu. ${ }^{33}$

Penggunaan kurikulum yang berorientasi kepada tujuan, menuntut partisipasi aktif dari pihak pendidik dan peserta didik, karena dengan tujuan yang jelas masing - masing pihak dapat mencari dan menemukan bahan, metode, dan

\footnotetext{
${ }^{31}$ Abuddin Nata, Filsafat Pendidikan Islam, ( Cet, I; Jakarta: Logos Wacana Ilmu, 1997 ), h. 124

${ }^{32}$ Hasan Langgulung, Asas - asas Pendidikan Islam, ( Cet. I; Jakarta: Pustaka Al Husna, 1987 ), h. 483

${ }^{33}$ Abbuddin Nata., op. cit h. 125
} 
129| MUSA WA, Vol. 12 No.1 Juni 2020 : 108-139

alat yang digunakan dalam rangka mencapai tujuan tersebut. Paling penting ditekankan adala keterlibatan aktif peserta didik, untuk berusaha dan menemukan inovasi yang baru, sehingga metode belajar aktif dari peserta didik sangat cocok dikembangkan.

Kurikulum yang materinya tidak diambil dari lingkungan peserta didik akan tidak menarik perhatian dan minatnya. Terlebih lagi bila kurikulum itu disusun tanpa memperhitungkan kebutuhan peserta didik, motivasi untuk mempelajari materi itu menjadi berkurang dan akan terasa sulit dikerjakan. Kurikulum harus bersinergi dengan pendidik, sebagai pelaksana kurikulum. Pendidik dituntut bersikap positif dan menggunakan seluruh kemampuannya sehingga transfer (pemindahan) ilmu kepada peserta didik dapat berlangsung secara positif pula.

\section{Peranan Orang Tua Terhadap Prestasi Belajar Anak}

Menurut Edy Suhardono makna dari kata peran adalah suatu penjelasan yang merujuk pada konotasi ilmu sosial, yang mengartikan peran sebagai suatu fungsi yang dibawakan seseorang ketika menduduki suatu karakterisasi (posisi) dalam struktur sosial. ${ }^{34}$

Sedangkan Peter Warsley, mengartikan peran sebagai seperangkat alat-alat yang telah dikembangkan oleh para sosiolog untuk menggarap hubunganhubungan yang kompleks. ${ }^{35}$ Kemudian Abu Ahmadi dkk, peran adalah suatu kompleks pengharapan manusia terhadap caranya individu harus bersikap dan berbuat dalam situasi tertentu berdasarkan status dan fungsi sosialnya. ${ }^{36}$

Dari penjelasan diatas, dapat ditarik sebuah kesimpulan bahwa yang dimaksud dengan peranan orang tua adalah keikutsertaan orang tua dalam membina kehidupan rumah tangga secara lahir batin yang menyangkut kewajiban dirinya terhadap anaknya.

34 Edy Suhardono, Teori Peran (Konsep, Derivasi dan Implikasinya), (Jakarta: PT. Gramedia Pustaka Utama, 1994), 3,

${ }^{35}$ Peter Warsley et.al (Alih Bahasa Hartono Hadi Kusumo), Pengantar Sosiologi Sebuah Pembanding, (Yogyakarta: PT. Tiara Wacana, 1992), 25.

${ }^{36}$ Abu Ahmadi dkk, Psikologi Sosial, (Jakarta: Rineka Cipta, 1991), 115 
Peranan orang tua terhadap pendidikan anak dalam keluarga besar sekali pengaruhnya dalam membentuk dasar kepribadian anak, hal ini sesuai dengan perkataan Zakiyah Darajat, bahwa :

"Pada umumnya pendidikan dalam rumah tangga itu bukan berpangkal tolak dari kesadaran dan pengertian yang lahir dari pengetahuan mendidik, melainkan karena secara kodrati suasana dan strukturnya memberikan kemungkinan alami membangun situasi pendidikan. Situasi pendidikan itu terwujud berkat adanya pergaulan dan hubungan pengaruh mempengaruhi secara antara orang tua dan anak.",37

Pendidikan oleh orang tua dalam keluarga, meskipun tidak langsung diberikan atau diajarkan kepada anak, adalah merupakan peletak dasar pembentukan kepribadian itu sendiri. Sikap dan tingkah laku orang tua akan dicontoh dan dijadikan modal dasar tingkah laku anak. Oleh karena itu sebagai orang tua harus selalu mawas diri dan juga selalu hati-hati terutama jika mau menjadi tauladan yang baik terhadap anak.

Tanggung jawab mendidik anak, maka yang menjadi penanggung jawab yang utama adalah orang tua, karena orang tualah yang memegang peranan yang sangat penting dalam pendidikan anaknya. Oleh karena itu orang tua merupakan pendidik yang utama bagi anak, sebab mereka yang pertama dikenal oleh anak sejak lahir.

\section{a. Peranan Ibu Terhadap Pendidikan Anak}

Sebagaimana kita ketahui bersama, bahwa ibulah yang memegang peranan penting dalam pendidikan anak, karena sejak dalam kandungan hingga lahir ibulah yang selalu dekat dengannya. Ibulah yang memberikan minum, memeliha, melindungi serta mendidik dan selalu dekat bergaul dengan anak-anak sehari semalam. Oleh sebab itulah kebanyakan anak-anak lebih cinta kepada ibunya daripada anggota keluarga lainnya.

Pada hakekatnya pendidikan ibu terhadap anaknya itu adalah suatu urusan yang tidak dianggap ringan dalam pelaksanaannya. Karena pendidikan ibu itu sesuatu pekerjaan yang harus dilaksanakan dengan penuh tanggung jawab. $^{38}$

\footnotetext{
${ }^{37}$ Zakiyah Darajad, Ilmu Pendidikan Islam, (Jakarta, Bumi Aksara, 1996), 35

38 Boehori, Membina Rumah Tangga, (Bandung: Al-ma'arif, 1977), 5
} 
131 | MUSA WA, Vol. 12 No.1 Juni 2020 : 108-139

Dengan demikian betapa mulianya pendidikan ibu yang mempunyai tugas dan tanggung jawab yang besar baik sebagai pendidik maupun pengatur rumah tangga. Adapun peranan ibu dalam pendidikan anaknya sebagai berikut.

a. Sumber dan pemberi kasih sayang

b. Pengasuh dan pemelihara

c. Tempat mencurahkan isi hati

d. Pengaruh kehidupan dalam rumah tangga

e. Pembimbing hubungan pribadi

f. Pendidik dalam segi emosional. ${ }^{39}$

Berpijak dari penjelasan di atas, maka peranan ibu adalah sangat penting terhadap pendidikan anak-anaknya.

b. Peranan Ayah terhadap Anak-Anaknya

Peranan seorang ayah terhadap anak-anaknya juga tidak kalah pentingnya terhadap peranan ibu dalam pendidikan, atau pembentukan sikap dan tingkah laku anak-anak. Apabila seorang ayah memberikan keteladanan yang baik dalam keluarga, maka akan terkesan baik pula pada hati anak-anaknya. Namun banyak terjadi kepincangan-kepincangan dalam pendidikan yang dilakukakan oleh seorang ayah dimana sang ayah selalu sibuk mencari nafkah keluarga dan tidak mempunyai waktu bergaul dengan anak-anaknya, serta menganggap bahwa pendidikan anak-anak menjadi tanggung jawab istri.

Pendapat yang demikian adalah pendapat yang keliru karena sebenarnya pendidikan anak-anak itu menjadi tanggung jawab mereka berdua (suami istri) dan ada kebersamaan suami istri dalam melakukan amanat Allah untuk mendidik anak-anak mereka. berikut :

Adapun peran ayah dalam pendidikan anak-anaknya adalah sebagai

a. Sumber kekuasaan didalam keluarga

b. Penghubung intern keluarga dengan warga masyarakat atau dengan dunia luar

c. Pemberi perasaan aman bagi seluruh keluarga

d. Pelindung terhadap ancaman dari luar

e. Hakim atau yang mengadili jika ada perselisihan. ${ }^{40}$

\footnotetext{
${ }^{39}$ Djumbransyah Indar, Ilmu Pendidikan Islam, (Malang: Biro Ilmiah IAIN Sunan Ampel, 2003), 74

${ }^{40}$ Ibid, 75
} 
Berdasarkan peranan atau fungsinya, ayah dalam pendidika anak juga berperan besar didalamnya. Oleh karena itu suami istri harus bekerja sama dan kompak dalam mendidik anak-anaknya demi masa depan anak, agar mereka bisa menjadi manusia yang berguna sesuai dengan harapan bangsa dan masyarakat serta orang lain.

Orang tua merupakan pendidik utama dan pertama bagi anak-anak mereka, karena dari merekalah anak mula-mula menerima pendidikan.dengan demikian bentuk dari pertama pendidikan dalam kehidupan keluarga. Orang tua (ayah dan ibu) memegang peranan penting dan amat berpengaruh atas pendidikan anakanaknya. Sejak seorang anak lahir, ibulah yang selalu ada disampingnya.

Meniru perangai ibunya dan biasanya seorang anak lebih cinta kepada ibunya, apabila ibu itu mejalankan tugasnya dengan baik. Ibu merupakan orang yang mula-mula dikenal anak, yang mula-mula dikenal anak, yang mula-mula menjadi temannya dan yang mula-mula mempercayainya, kecuali apabila ia ditinggalkan.

Dengan memahami segala sesuatu yang terkandung didalam hati anaknya dan jika anak telah mulai agak besar, disertai kasih sayang, dapatlah ibu mengambil hati anaknya untuk selama-lamanya. Pengaruh ayah terhadap anaknya besar pula. Dimata anaknya ia seorang yang tertinggi gengsinya dan terpandai diantara orang-orang yang dikenalnya.

Cara ayah itu melakukan pekerjaannya sehari-hari berpengaruh pada cara pekerjaan anaknya. Ayah merupakan penolong utama, lebih-lebih bagi anak yang sudah besar, baik laki-laki maupun perempuan, bila ia mau mendekati dan dapat memahami hati anaknya.

Pada dasarnya kenyataan-kenyatan yang dikemukakan diatas itu berlaku dalam kehidupan keluarga atau rumah tangga dengan bagaimanapun juga keadaannya. Hal ini menunjukan ciri-ciri dari watak rasa tanggung jawab orang tua atas kehidupan anak-anak mereka untuk masa kini dan masa mendatang. 
Bahkan para orang tua umumnya merasa bertanggung jawab atas segalanya dari kelangsungan hidup anak-anak mereka. ${ }^{41}$

Karenanya tidaklah diragukan bahwa tanggung jawab pendidikan secara mendasar terpikul kepada orang tua. Apakah tanggung jawab pendidikan itu diakuinya secara sadar atau tidak, hal itu adalah merupakan "fitrah" yang telah dikodratkan Allah swt yang dibebankan kepada mereka. Berbicara tentang tanggung jawab orang tua terhadap pendidikan anak amatlah penting dan berlangsung sejak anak masih dalam kandungan hingga tumbuh menjadi manusia yang mampu mengembangkan diri pribadinya. Tanggung jawab tersebut terdiri dari beberapa aspek, yaitu aspek moral, aspek intelektual dan aspek sosial.

a. Tanggung Jawab Moral

Tanggung jawab orang tua dalam bidang moral merupakan tanggung jawab pendidikan yang erat hubungannya dengan soal budi pekerti dan keimanan dengan Tuhan Yang Maha Esa. Tanggung jawab ini merupakan landasan utama untuk membentuk kepribadian dimasa yang akan datang.

Agar para orang tua dapat menunaikan tanggung jawabnya dengan baik maka perlu sikap tekun, ulet, sabar dan hati-hati dalam mengarahkan putraputrinya, karena pada dasarnya anak merupakan individu yang penuh dengan gejolak, bersifat dinamis yang selalu berkembang sesuai dengan tingkat perkembangan masing-masing. Supaya anak dapat tumbuh berbudi dan berkepribadian menarik maka hendaknya para orang tua :

1. Memberi suri tauladan yang baik dan benar, sebab anak merupakan mahluk yang suka meniru,lebih-lebih dari perbuatan orang tuanya.

2. Mau dan mampu mengontrol lingkungan pergaulannya.

3. Mau mengatasi bahan bacaan anak, sudah patutkah bacaan-bacaan anak tersebut jika ditinjau dari segi umum atau tingkat perkembangan anak.

4. Jangan sekali-kali memberi peluang untuk anak melihat film, gambargambar yang bersifat merangsang pada tindak kejahatan.

b. Tanggung jawab orang tua dalam segi intelektual. ${ }^{42}$

Menuntut ilmu merupakan kewajiban semua umat manusia, karena dengan belajar seseorang akan memiliki kelebihan jika dibandingkan dengan orang-orang

\footnotetext{
41 Zakiyah Darajad, Dkk; Ilmu Pendidikan Islam,(Jakarta: Bumi Angkasa, 1996), 36

${ }^{42}$ Ibid, 40
} 
yang tidak berilmu. Agar anak berilmu dan bermoral tinggi sudah selayaknya ia dibiasakan dengan hal-hal yang baik dan diberi tugas sesuai dengan tingkat kemamauan anak.

Pada dasarnya pendidikan dimasa kecil akan menuntut sikap dan sepak terjang seseorang dimasa akan datang, hal tersebut disebabkan pada masa itu pikiran anak masih jernih, ingatannya sangat kuat dan semangat belajarnya sangat tinggi. Dari sini dapat disimpulkan bahwa anak itu telah berkembang sejak usia masih dini, oleh karena itu pendidikan harus dilaksanakan sejak sedini mungkin, agar pendidikan dapat berhasil sesuai dengan yang diharapkan.

c. Tanggung Jawab Orang Tua Dalam Segi Sosial

Pendidikan sosial adalah pendidikan anak sejak dini agar terbiasa melakukan tatakrama sosial yang utama, yang bersumber dari aqidah Islamiyah yang abadi dan emosi kaimanan yang mendalam dimasyarakat.

Tanggung jawab ini erat kaitannya dengan usaha membekali anak dalam menjalankan dengan segi sosial yang baik dengan dasar-dasar psikis yang mulia. Telah dimaklumi bersama bahwa manusia itu disamping berfungsi sebagai mahluk individu yang selalu mementingkan kehidupan pribadinya, juga berfungsi sebagai mahluk sosial ia berkewajiban untuk selalu memperhatikan dan menghormati hak-hak orang lain yang berdasarkan pada rasa kemanusiaan dan persamaan hak. Sebagai mahluk sosial ia dituntut untuk mengontrol diri pribadinya.

Dengan demikian seseorang akan cepat mengetahui kekurangan yang ada pada dirinya, dan selanjutnya ia dapat mengadakan pembenahan demi kesuksesan bersama. Agar cita-cita tersebut terwujud dengan baik kunci keberhasilannya pada dasarnya terletak pada individu-individu itu sendiri. Sebab pada hakekatnya kehidupan masyarakat (bernegara) itu terbentuk dari adanya kesatuan dan persatuan dari pribadi yang merdeka. Dan jika para individu tersebut tidak bertanggung jawab, akibatnya sudah dapat diduga tata kehidupan tersebut akan tetap sirna.

Dalam uraian tersebut diatas, dapat disimpulkan bahwa keluarga ialah lingkungan pertama dan utama anak dimana ia memperoleh pengaruh prestasinya 
135 | MUSA WA, Vol. 12 No.1 Juni 2020 : 108-139

dalam pendidikan sekolah. Keberhasilan belajar anak disekolah tergantung dari upaya orang tua dalam keluarga untuk memberi pengarahan kepada anakanaknya, terutama dalam segi intelektualnya.

Orang tua bertanggung jawab atas pendidikan anak-anaknya dalam semua segi, baik itu segi moral, sosial maupun intelektualnya. Tanggung jawab orang tua dalam pendidikan anak adalah juga menumbuhkan potensi jasmani dan rohani anak, untuk mendapatkan nilai-nilai tertentu, seperti nilai keakhlakan, nilai ketertiban, ketentraman dan nilai-nilai lainnya. Dalam kegiatan pendidikan atau anak tersebut berlangsung ditiga tempat yaitu : keluarga, sekolah dan masyarakat. Ketiga lembaga ini merupakan tempat berlangsungnya kegiatan yang dapat menolong anak didik dalam perkembangan jasmani dan rohani, agar mencapai tingkat kedewasaan yang mampu berdiri sendiri untuk memenuhi tugas sebagai makhluk sosial dan sebagai individu.

Namun harus diingat bahwa anak sejak lahir tidak menjadi tanggung jawab sekolah. Hal ini berarti anak-anak sudah diserahkan tidak seluruhnya menjadi tanggung jawab sekolah. Sekolah hanya bersifat melanjutkan pendidikan anakanak yang telah dilaksanakan dilingkungan dikeluarga. Berhasi tidaknya pendidikan anak yang diperoleh dari orang tua atau keluarganya.

Pendidikan dalam keluarga merupakan dasar atau potensi dari pendidikan anak mengenal pendidikan pertama dan utama dalam meletakkan dasar-dasar kepribadian. Anak merupakan suatu keinginan dan dambaan setiap orang tua yang paling dominan dalam kehidupan berumah tangga.

Kehadiran anak dalam rumah tangga merupakan karunia Allah swt, kepada orang tua supaya dijaga, dipelihara dan diberi pelajaran untuk kebahagiaan orang tua itu sendiri. Sebagai pemegang amanat dari Allah swt, orang tua harus sanggup menanamkan pendidikan sebaik mungkin kepada anak melalui kebiasaan latihanlatihan, serta pemahaman lain yang dianggap perlu dan menguntungkan bagi perkembangan anak dalam mencapai kematangan baik jasmani dan rohani.

\section{KESIMPULAN}

Keluarga merupakan media pendidikan utama terhadap perkembangan peserta didik, untuk mengembangkan potensi yang dimiliki baik jasmani maupun 
rohani. Berbagai langkah tersebut dapat ditempuh dengan optimalisasi peran lingkungan keluarga dalam melakukan peranannya sebagai lingkungan pendidikan. diantara peran tersebut sebagai berikut:

a. Mendidik peserta didik di lingkungan keluarga, mendidik peserta didik dalam lingkungan keluarga ditempuh dengan berbagai cara diantaranya: Memperhatikan kemajuan peserta didik, terlibat dalam kegiatan belajar, menciptakan suasana belajar, memberi bimbingan belajar, serta memberi motivasi belajar kepada peserta didik.

b. Menjalin keakraban relasi anggota keluarga, pentingnya relasi atau hubungan yang baik dalam sebuah keluarga akan membawa hasil yang baik, yang meliputi harmonisasi, kasih sayang, serta kebersamaan dari jalinan hubungan yang harmonis tersebut memudahkan aktifitas pembinaan dalam keluarga hingga prestasi belajar peserta didik dapat dicapai dengan mudah.

c. Memenuhi kebutuhan belajar peserrta didik. Fasilitas belajar merupakan hal yang dapat mempermudah dan memperlancar pelaksanaan suatu usaha yang dilakukan terutama dalam belajar. Teknik dalam memenuhi kebutuhan belajar peserta didik yang dilakukan dalam lingkungan keluarga adalah: menyediakan fasilitas dengan melengkapi sarana belajar. Seperti pemenuhan buku-buku pelajaran, sarana pelengkap dan ruang belajar yang kondusif.

d. Menciptakan budaya beragama dalam lingkungan keluarga. Keluarga berperan sebagai faktor pelaksana dalam mewujudkan nilai-nilai, keyakinankeyakinan dan persepsi budaya dan agama terhadap anak-anaknya (peserta didik). Di dalam lingkungan keluarga, orang tua berkewajiban untuk menjaga, mendidik, memelihara, serta membimbing dan mengarahkan dengan sungguh-sungguh dari tingkah laku atau kepribadian anak sesuai dengan berdasarkan atas tuntunan atau aturan yang telah ditentukan dalam agama, baik dengan nasehat, anjuran atau pengajaran.

Berdasarkan pada kenyataan tersebut dapat penulis paparkan bahwa lingkungan keluarga merupakan salah satu pusat pendidikan dengan optimalisasi peran yang dimainkan terhadap peserta didik dengan menjalin keakraban antara 
137| MUSA WA, Vol. 12 No.1 Juni 2020 : 108-139

sesama, memenuhi kebutuhan belajar serta menciptakan suasana religius dalam lingkungan keluarga maka berpotensi untuk menghasilkan prestasi belajar.

Prestasi belajar merupakan kemampuan peserta didik dalam mencapai materi pelajaran tertentu sesuai kurikulum, waktu dan kriteria tertentu. Pretasi belajar peserta didik banyak dipengaruhi oleh berbagai faktor dari luar dirinya (eksternal). Pretasi yang dicapai siswa pada hakekatnya merupakan hasil interaksi dengan lingkungannya, yakni lingkungan keluarga dan lingkungan sekolah yang menjadi sentral pendidikan.

a. Lingkungan kelurga. Pengaruh keluarga dalam pendidikan anak sangat besar dalam berbagai macam sisi. Keluargalah yang menyiapkan potensi pertumbuhan dan pembentukan kepribadian anak. Lebih jelasnya, prestasi belajar peserta didik tergantung pada pemikiran dan tingkah laku kedua orang tua dan anak-anaknya serta lingkungannya. Melalui berbagai macam pembinaan, dukungan, pemenuhan kebutuhan serta dorongan nilai-nilai spiritual dapat mengantarkan peserta didik mencapai prestasi gemilang dalam belajar.

b. Lingkungan sekolah. Lembaga pendidikan formal yang memiliki tugas dan fungsi menyelenggarakan proses pendidikan adalah identitas sekolah. Kegiatan pendidikan dilaksanakan secara tertib, terencana dan teratur. Melalui pemenuhan sarana dan prasarana belajar, kualitas tenaga pendidik serta koordinasi dengan lingkungan keluarga merupakan faktor yang dapat mewujudkan prestasi dalam belajar peserta didik.

\section{DAFTAR PUSTAKA}

A. K. Baihaqi. Mendidik Anak Dalam Kandungan Menurut Pedagogis Islam. Cet. I; Jakarta: Darul Ulum Press, 2000

Ahmadi, Abu dkk. Psikologi Sosial. Jakarta: Rineka Cipta, 1991

Ali, Mohammad Daud. Pendidikan Agama Islam. Cet. II; Jakarta: PT. Raja Grafindo Persada, 1998

Ali, Muhammad. Guru Dalam Proses Belajar Mengajar. cet. IX; Bandung: Sinar Baru Algensido, 1996 
Asmuni, H.M. Yusran. Psikologi Pendidikan. Jakarta: Gema Insan Press, 1988

Boehori. Membina Rumah Tangga. Bandung: Al-ma'arif, 1977

Daradjat, Zakiah. Ilmu Jiwa Agama. Cet.VIII; Jakarta: Bulan Bintang, 1989

Darajad Zakiyah, Dkk. Ilmu Pendidikan Islam. Jakarta: Bumi Angkasa, 1996

Darajad, Zakiyah. Ilmu Pendidikan Islam. Jakarta, Bumi Aksara, 1996

Engkoswara. Dasar - Dasar Metodologi Pengajaran. Cet, II; Jakarta: Bina Aksara, 1988

Harahap, E.St. dkk. Kamus besar bahasa Indonesia. Bandung: Balai Pustaka, 2007

Hawari, Dadang. Al-Qur'an, Ilmu Kedokteran Jiwa dan Kesehatan Jiwa. Cet, IX; Yogyakarta: PT. Dana Bhakti Prima Yasa, 1999

Indar, Djumbransyah. Ilmu Pendidikan Islam. Malang: Biro Ilmiah IAIN Sunan Ampel, 2003

Jalal, Abdul Fattah. Min al-Ushulit at-Tarbawiyah Fi al-Islam, Alih Bahasa Herry noer Ali, dengan judul Azaz - azaz Pendidikan Islam. Cet., I; Bandung: CV. Diponegoro, 1988

Kementrian Agama RI. Alquran dan Terjemahnya. Jakarta: PT. Sinergi Pustaka, 2012

Langgulung, Hasan. Asas - asas Pendidikan Islam. Cet. I; Jakarta: Pustaka Al Husna, 1987

N. K., Roestiyah. Masalah - Masalah Ilmu Keguruan. cet. I; Jakarta: PT. Bina Aksara, 1982

Nata, Abuddin. Filsafat Pendidikan Islam. Cet, I; Jakarta: Logos Wacana Ilmu, 1997

Poerwadarminta, W. J. S. Kamus Umum Bahasa Indonesia. Cet. VI; Jakarta: PN. Balai Pustaka, 1983

Sagala, Syaiful. Konsep dan Makna Pembelajaran. Cet. IV; Bandung: CV. Alfabeta, 2006 
139| MUSA WA, Vol. 12 No.1 Juni 2020 : 108-139

Shaleh, Abdul Rachman. Pendidikan Agama Islam dan Pembangunan Watak Bangsa. Edisi, Jakarta : PT. Raja Grafindo Persada, 2005

Silberman, Melvin L. Active Learning: 101 Strategies to Teach Any Subject, diterjemahkan oleh raisul muttaqien, Active Learning: 101 Cara Belajar Siswa Aktif. Cet. I; Bandung: Nusamedia dan Nuansa, 2004

Sudjana, Nana. Cara Belajar Siswa Aktif Dalam Proses Belajar Mengajar. Cet. III; Bandung: Sinar Baru Algensido, 1996

Suhardono, Edy. Teori Peran (Konsep, Derivasi dan Implikasinya. Jakarta: PT. Gramedia Pustaka Utama, 1994

Tadjab. Perbandingan Pendidikan Studi Perbandingan Tentang Beberapa Aspek Pendidikan Berat Modern, Islam dan Nasional. Cet. I: Surabaya: Karya Abditama, 1994

Tafsir, Ahmad. Ilmu Pendidikan dalam Prespektif. Cet, II; Bandung: PT. Remaja Rosdakarya, 1994

Uno, Hamzah B. Landasan Pendidikan. Cet. I; Gorontalo: Nurul Jannah, 2003

Warsley, Peter. et.al (Alih Bahasa Hartono Hadi Kusumo), Pengantar Sosiologi Sebuah Pembanding. Yogyakarta: PT. Tiara Wacana, 1992

Winkel, W. S. Psikologi Pengajaran. Cet, II; Jakarta: PT. Gramedia, 1989 